\title{
Joyful Colors in Krishna Prakash Shah's Abstract Artworks
}

\section{Yam Prasad Sharma}

Lecturer in English, Lalitkala Campus

Tribhuvan University, Kathmandu, Nepal

Email: yamprasadsharma@gmail.com

DOI: https://doi.org/10.3126/irjmmc.v2i3.40056

Received: August 05, 2021; Revised \& Accepted: September 15, 2021; Published: September 29, 2021

(C) Copyright: Sharma (2021).

\section{ABSTRACT}

Aesthetic pleasure and joy are the dominant features of Krishna Prakash Shah's colorful compositions. Shah, one of the renowned contemporary Nepali abstract artists, presents art forms without referential and recognizable contents. In other words, the form itself is its content. The works have the power to arouse rapture and relish through harmonious colors although the viewers may not able to find fixed significance. Coherent colors, rhythmic waves, playful shapes and organic composition in his paintings contribute to create beauty and provide aesthetic pleasure to the viewers. This research paper analyzes Shah's abstract paintings from the perspective of aestheticism and traces joyful colors and rhythmic waves in his works. The study uses qualitative methods of research since there can be multiple interpretations of the same artwork, and the subjectivity of the critic has a significant role to derive the thesis statement.

Keywords: Aestheticism, aesthetic pleasure, abstract art, rhythmic waves, joyful colors

\section{INTRODUCTION}

Krishna Prakash Shah, the winner of a dozen national-level awards including 'National Fine Arts Award 2021' provided by Nepal Academy of Fine Arts (NAFA), is a contemporary Nepali artist. He has been contributing to the field of Nepali art for three decades through the creation of art, particularly abstract paintings, and the research in abstract arts (Shah, 2012). His research work Nepali Abstract Paintings: A Development Analysis, recently published by NAFA, explores the beginning, development and significant features of Nepali abstract paintings. He has three solo art exhibitions in Nepal, three solos in Europe, and more than one hundred group exhibitions of his artworks.

Shah's artworks do not refer to the objects, persons and events of the external world. The colors, waves, shapes and brushstrokes stand for themselves (Ausstellung Nepal, 2015). The artist has not used these elements to create images and figures that represent the visible, tangible and recognizable things in the world. It is almost impossible to pinpoint the fixed significances of the art form since one cannot find objectively represented figures in his abstract canvas. Nevertheless, the art forms convey a sense of rhythm in lines and colors that provide aesthetic pleasure to the viewers. The combination of colors and composition of shapes have created beauty and joy in art (Shah, 2007). The art form stands for its own sake without recognizable contents. In other words, the form is its own content (Sharma, 2012). 
Such features are found in abstract arts. The features of abstract art are elaborated in a separate part of this paper.

Aestheticism is a perspective that looks at art in terms of its beauty and the aesthetic pleasure it provides to the viewers irrespective of meaning and moral lesson. The things of everyday use like food, furniture, clothes and pen are important for their functional purpose in life but works of art have aesthetic value. We read poems, sing songs, listen to music, view paintings and sculptures, watch dramas and films for pleasure but not to learn moral lessons though we may have that on the process of appreciation. The function is not the main focus of art. The concept of aestheticism is elaborated separately and applied as a tool to analyze Krishna Prakash Shah's abstract compositions.

\section{LITERATURE REVIEW}

In the process of research, available literature has been reviewed to find the research gap and to connect this paper with other researches. According to Dhungel (2064), Krishna Prakash Shah's refined works provide a new feeling of color and music. We can dive deep into navarasa (nine raptures) of color sensation and music. The more we view the paintings the more we reach the depth. His works leave a long-lasting impression. We would like to dissolve ourselves in the images of the paintings. We like to touch the images. It is felt that life is swinging in the rhythm of sensation created by colors in the canvas. The paintings cannot be understood by relating them to the external world through reasoning but by diving into the artworks themselves. Shah's paintings have been created through the power of imagination (Sharma, 2021). Shah has included black, red, white, blue and yellow colors in his paintings. Black color is the symbol of darkness and ignorance. White is the symbol of knowledge and self-realization. The cluster of light is the mirror of a bright soul. Red symbolizes the feeling of victory and revolution. The blue symbolizes the state of peace whereas yellow is the symbol of purity. In his paintings, he has depicted the brighter world beyond knowledge and the perception of the external world. The combination of colors is distinctly heart-rending. A sense of peace and spirituality are other aspects of his works (Dhungel, 2064).

Khanal (2019) states that Krishna Shah's abstract paintings are about internal feelings. The art expresses the abstract concepts in colors, lines and shapes that cannot be represented in words. The paintings are able to lead the viewers to the depth of serenity and peace. Powerful forms with a dynamic flow of colors take the viewers along with them (Shah, 2021). Shah's artworks present the artist's quest for peace. He has captured positive sensations and feelings on the canvas through his musical colors and lines (Khanal, 2019).

Sharma (2012) writes about Shah's paintings that his flowing images and colors, and the magnetic power of the canvas invite the viewers to enter the canvas where they swing together with spontaneous music of the lines and colors. The movement takes us on the adventurous journey to the unknown setting and horizon. The pulsating life of the artwork swings us toward the edges and center again and again. We are not conscious of our own existence. In other words, we happen to be the color, music and unrecognizable moving shapes. Thus, the viewing subject assimilates itself with the viewed object, the work of art. As new thoroughfares are still not explored, the ride keeps on galloping. It is hard to disconnect 
ourselves from the sweeping color field. The colors and the forms are not employed to represent some content or signify certain meanings. In other words, the colors and forms themselves are the essence and contents. Each canvas is the presentation of the frozen music unfolding in space (Sharma, 2021). The musical form has soothing and consoling effects. A color walks hand in hand with the other in harmony. One image fits aptly with the other creating cohesion and pattern. As one element elegantly connects to the next, all the constituents hang in harmony as the cells and organs as in a living being. His works seem to remain ever new in the sense that we encounter novel images and paths to go through in our first viewing. In the subsequent viewing, we take the new route to explore the canvas, we reach the new horizon of our imagination. The more we look the more comforting shapes we visit. Thus, the painting remains forever new. The painting breaks our monotony, lengthens and engages our perception (Sharma, 2012).

In the article "Shahka Chitrabare Antarkriya", Saurya National Daily (2012, p.16) states that Shah has created paintings related to human imagination that brings visions of invisible things having rhythm and sensation. In "Krishnaka Chitrama Manashanti", the national daily newspaper Rajdhanai (2012) mentions that rhythmic lines, coherent colors and harmonious shapes provide a sense of music and peace of mind. In the article "Introduction to Creator of Cover Art", Madhupark (2009, p.3) states that his works convey the message that knowledge is the true salvation that is achieved giving shape to the invisible aspects of reality. From this literature review, it is found that Shah's paintings have been analyzed and critiqued in various ways but aesthetic aspects of the compositions like joyful colors and rhythmic waves have not been explored well.

\section{RESEARCH GAP}

Various researchers and writers have analyzed Krishna Prakash Shah's abstract paintings from various angles but his artworks have not been studied from the perspective of aestheticism. The significances of colors in his works have not been explored. This paper fulfills this gap.

\subsection{Research Questions}

This research paper answers the following questions:

1. Why does not Shah use representational images and figures of external world in his compositions?

2 . Why does the artist use only colors for his expressions?

3 . What is the significance of those colors?

\subsection{Research Objectives}

The research paper has the following objectives:

- to clarify the concepts of abstract art and aestheticism

- to find the significances of the colors in Shah's artworks

\section{MATERIALS AND METHODS}

The research area is Krishna Prakash Shah's abstract paintings which have been analyzed from the perspective of aestheticism as a tool for interpretation and analysis. Since the artworks can be interpreted from multiple perspectives, and the critic's subjectivity affects 
the interpretation and criticism, the paper uses qualitative methods of research. Books and articles on arts and aesthetics are secondary sources that have been used to create background, review literature and clarify the research tool. Abstract compositions of Krishna Shah are the primary sources that have been analyzed and interpreted. In addition to this, the researcher took the interviews of the artist and art critics.

\subsection{Abstract Art}

Before the discussion of Shah's abstract paintings, it would be worth to clarify the concept of abstract art. Abstract art disconnects itself from the objects and events of the external world, and art form and colors are not the means to convey meaning but ends in themselves. The art "form is significant not because it informs about our world but because the form is its own significance" (Martin \& Jacobus, 1991, p.75). The viewers make their own links in lines, colors, and shapes. The viewers paint their own compositions in their minds which provide the "spots of time", a sense of aesthetic pleasure, in William Wordsworth's term (Martin \& Jacobus, 1991, p.77). In subsequent viewings, the viewers make a different connection and create other new compositions. In this sense, the painting remains forever new. Different viewers approach the painting in a different manner. Thus, abstract painting does not have a fixed form but an open-ended one.

Abstract form does not represent the objects and events of the world external world, so, viewers need not think about the past and future to connect the images with things. Then, an abstract form has presentational immediacy, and it is "timeless within time" (Martin \& Jacobus, 1991, p.82). Martin and Jacobus state that abstract paintings liberate us from the habits of referring to specific objects and events. Martin and Jacobus (1991) further add:

Then the radiant and vivid values of the sensuous are enjoyed for their own sake, satisfying a primal fundamental need. Abstractions can help fulfill this need if we dare, despite our habits of practice and Puritan heritage, to behold and treasure the images of the sensuous. . . Moreover, because references to specific objects and events are eliminated, there is a peculiar abstraction from the future and the past. Abstract painting, more than any other art, gives us an intensified sense of 'here-now' or presentational immediacy (p.76).

The qualities of images, colors and lines cause olfactory, aural, visual or tactile sensations stimulating our sense organs. In abstract painting, the sensation is not caused by the figures but by the abstract images, colors and lines (Sharma, 2014).

Abstract painting is an art of pure form without recognizable content, in which "only aesthetic elements seem to be present" (Schapiro, 1979, p.185). The art form breaks away from the classical concept of "artistic imitation" (Schapiro, 1979, p.186). The abstract composition makes the viewers free from the "tyranny of time and space and the fury of functions" (Martin \& Jacobus, 1991, p.81). Rebay (1938) states: "The contemplation of a non-objective picture offers a complete rest ... from earthly troubles and thought" (p.7). The artwork "suspends all corporeal activity" and the artist fully contemplates in the abstract form (Seuphor, 1960, p.26). In Kandinsky's abstract compositions, the "fluidity of painting" is like the "lyricism of music" (Matthews \& Platt, 2001, p.534). The liberated color and the formal 
independence enthrall the viewers. Abstract paintings are subjective and non-representational. In abstract compositions, aesthetic aspects are more dominant than the meanings and moral lessons.

\subsection{Aestheticism}

Aestheticism is the tool for interpretation of the paintings. Thus, the theory of aestheticism has been clarified in this part. Aestheticism, an art movement of the late nineteenth century, emphasizes aesthetic value and effects of literature, drama, dance, fine art and music (Fargis, 1998). It argues that art should be beautiful first rather than serving a moral purpose. It believes in the concept of art for art's sake (Denney, 2000). Emanuel Kant, Oscar Wilde and Walter Pater are the major theorists that focused on the joy and aesthetic value of a work of art. According to Kant (1992), art has purposiveness without purpose. It means creation has no purpose except to provide aesthetic pleasure. For him, all arts are useless. It means to say that arts may not have any moral lessons and may not be useful in everyday life like food, furniture and fashion items. Arts are more beautiful than nature, for nature has drawbacks and errors in making whereas arts capture beauty avoiding ugliness. Aestheticism challenged the values of mainstream conventional cultures that art fulfilled ethical roles in society. The aesthetic movement stood against materialism and consideration of material gain and loss.

Pater (1992) states that life has to be lived intensely with an ideal of beauty. In life, we should collect the invaluable gems of joyful experiences but it is difficult to gather more gems in life from physical things. However, it is possible in art, music and literature (Archer, 1989). In a very short time, we can experience many gems from creative works. There was not any real association between art and morality (McMullen, 1971).The followers of aestheticism believed that arts should present refined sensuous pleasure to the viewers, rather than convey moral messages to the public. As a result, they did not accept the concept of art as something moral or useful to everyday life (Welland, 1953). Instead, they believe that art does not have any didactic purpose, but it needed to be beautiful. They consider that beauty is the basic element of art (Mendelssohn, 2007). They also argue that life should imitate art. Nature is crude and lacking in appropriate design when it is compared to art (Burke, 1986). A suggestion is more important than an overt statement (Denisoff, 2007). There is a close connection in colors, words and rhythm. Music establishes mood in the creator and viewers. There is a constant striving for beauty and joy (Gal, 2015). The study uses aestheticism as a tool for analyzing and interpreting Krishna Shah's abstract composition.

\section{RESULT AND DISCUSSION}

Krishna Prakash Shah's abstract paintings primarily present beauty and joy in visual forms that provide aesthetic pleasure to the viewers. The art form renews and lengthens the viewers' perception though they may not be able to pinpoint the significances, meanings and moral lessons of the work, and it is not sure whether it has any meaning or no meaning at all. Rhythmic waves, coherent colors and the flow of well-connected shapes suggest a sort of ecstasy in visual melody. The visual elements give way to the imagination of unusual visions, images and concepts that create a vibration within us suggesting the musical movement of life. The romantic feeling of inner joy provides a sort of satisfaction. In this section, Krishna 
Shah's artworks are analyzed and interpreted in terms of their aesthetic elements and the possible pleasure they provide.

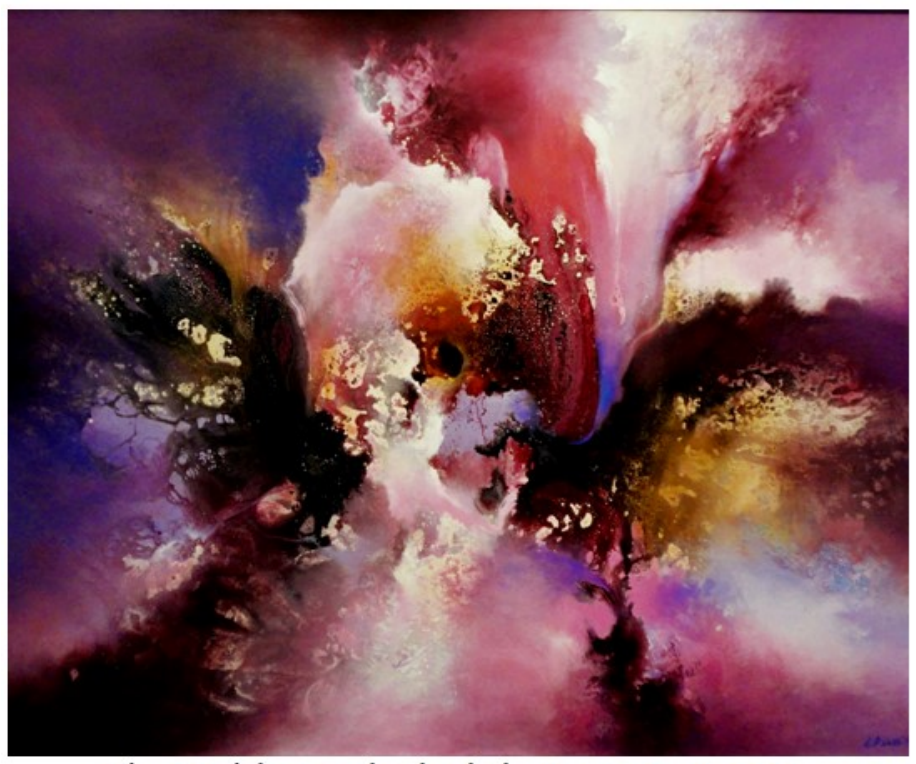

Fig.1 Krishna Prakash Shah. "Inner Joy", 2011

Shah's abstract painting "Inner Joy" (Fig.1) presents aesthetic pleasure through the creation of unusual and strange shapes and their rhythmic movement in the composition. The title itself suggests the joy created by coherent colors in the canvas. The term "inner" suggests that this joy is not perceived or experienced from the external material world but from within us which has been represented in this colorful composition. Since the artwork does not refer to external objects, characters and events, this creation is abstract. The concept "inner joy" itself is abstract, for it does not have visible, tangible and material existence. It is a matter to be felt and experienced, and the joy does not have a definite shape. Nevertheless, the artist gives visible shape to the invisible entity. The title corroborates the concept of the creation itself. About his artwork, Shah (2021) himself states:

My creativity emphasizes the brighter side of life leaving the dark emotions behind. Experience of inner peace and joy is possible in the meditative process. In a certain meditative mood, I disconnect from the material world of everyday reality. Then slowly, certain waves of joyous feelings start to emerge and shuttle back and forth creating self-experiencing bliss. I grasp this felt abstract visual impression of meditative mood, then express them using the appropriate colors and shapes in a work of visual art. (Interview)

Here the artist expresses his creative quest for inner joy within himself and abstract canvas. The colors and shapes in spontaneous rhythm provide a sense of musical movement in the canvas. In one view, the shapes are emerging from the center and expanding toward the periphery. In the next view, the shapes are moving toward the center. In this sense, the composition is playful suggesting multiple shapes and significances. Without direct reference, 
the composition provides the subjective experience of multiple gems of ecstasy like the depth of the blue sea, floating white clouds, sweeping glaciers, primitive caves, strange dark cliffs and novel images of our imagination. We receive aesthetic pleasure by moving through these colors and shapes.

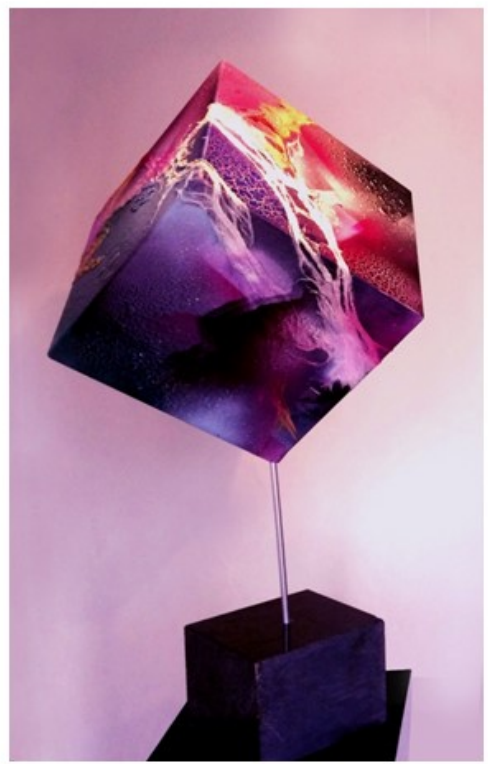

Fig. 2 Krishna Prakash Shah. "Beauty beyond the Real World", 2017

Shah's artwork "Beauty beyond the Real World" (Fig.2) captures the beautiful shapes that are beyond the physical world that we cannot see in our surroundings but in our imagination. The surface is the new world that we have never seen and visited. The colors create the scene of the spontaneous celebration of the carnival. The colors of sunset convey a sense of twilight zone between the bright day and dark night. The setting creates a meditative mood. Blurring the boundary between art genres, the work incorporates the aspects of both painting and sculpture, for the real cube with four surfaces presents multiple scenes of the imagination. The art is all-inclusive, for it incorporates multiple gems of beauty beyond the tangible reality. Some shapes dimly suggest lightening, milky way, erupting red-hot from the volcano, the creation, evolution and degeneration of matter, life and civilization. In other words, it is a bird's eye view of the entire universe. The work takes us to the tour of the new horizon beyond. In an interview, Shah (2021) states:

The ultimate target of human life is to get eternal bliss or unconditional happiness, but modern physical advancements have upshot numerous waves of miserable and unusual discords in humanity. Thus, modern civilization must come across with positive feelings through abstract paintings that can communicate positive thoughts and feelings. That will support being serene, healthy, and creative. (Interview)

The sole purpose of his work is to provide new sensations and aesthetic pleasure. The combination of coherent colors contributes to create beauty. 


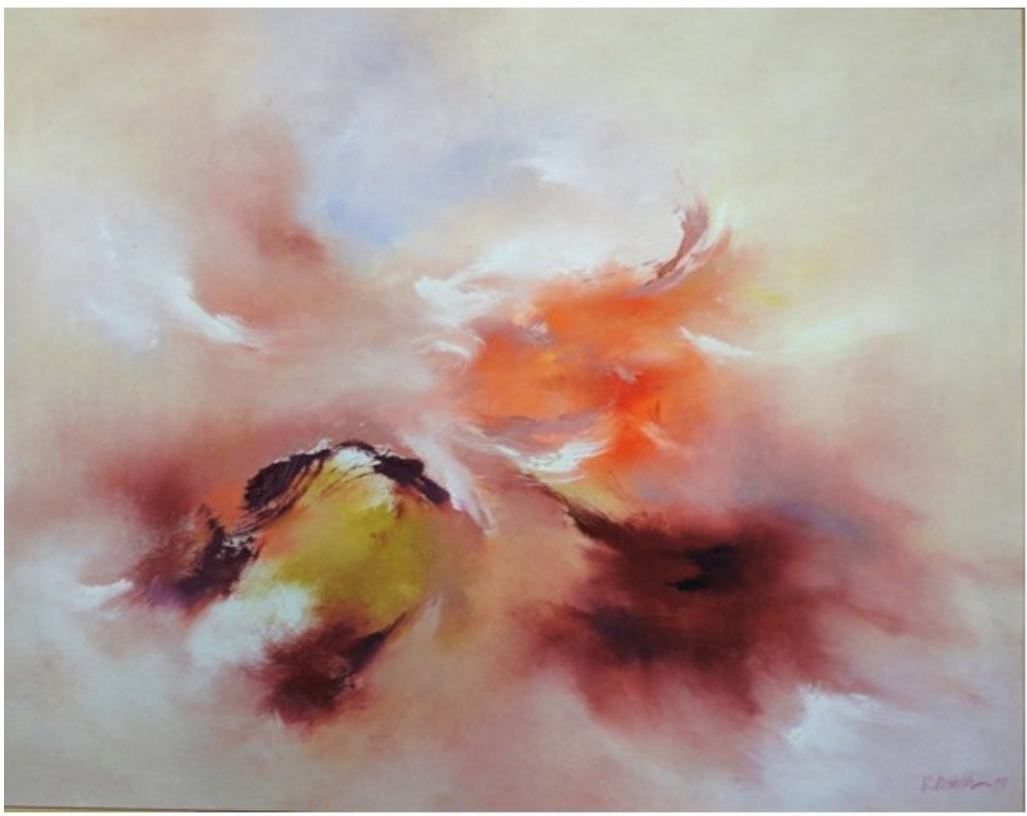

Fig. 3 Krishna Prakash Shah. "Color Carnival", 2012

Shah's composition "Color Carnival" (Fig.3) plays with the possibilities of colors with the spontaneous flow. The mild and gentle colors sweep across the space and gather at a point creating a unique shape for a moment but instantly, the provisional image begins to melt and diffuse in the wider surface. The motion of colors comes to the climax and swings back giving the impression of tides and waves existing for the moment and vanishing in eternity. The clouds in the sky make images and figures that constantly appear and disappear in a new disguise. The innovative shapes and colors directly appeal to our senses and provide pleasure though we do not know what they signify. In an interview, Shah (2021) states:

My creations share the rapture with joyful color, rhythmic shapes, and harmonious composition. Color is the most inevitable element that plays a vital role in my abstract arts. In the deep, soothing, and peaceful mood of meditation, our mind and soul both urge to reflect upon joyous feeling through the soul-touching effect of emotionally pleasurable color combination. In my creation, the artistic vibrancy is possible through texture that generates inner waves of feelings. (Interview)

To create such an effect, the artist has applied a challenging technique of partial soak and flow of liquid colors. The flow of colors on the surface creates smooth textureproviding unique harmony with finishing touch. 


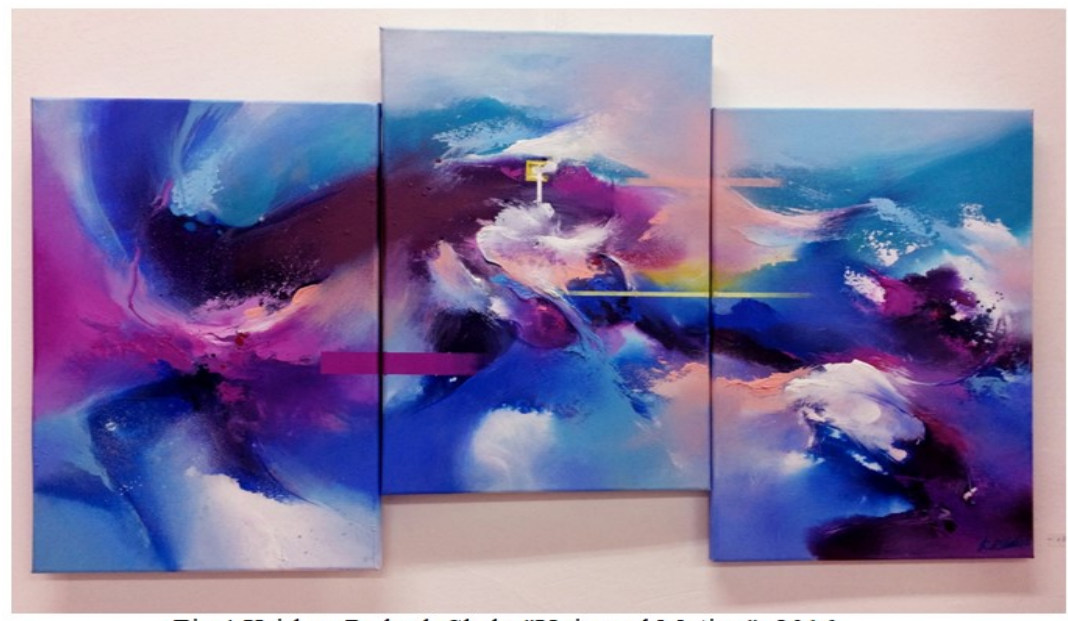

Fig.4 Krishna Prakash Shah. "Universal Motion", 2016

Shah's creation "Universal Motion" (Fig.4) captures a moment in the dynamic upheaval and turmoil in the universe. There is widespread flux and fluctuation in all the space. The movement of tectonic plates shakes the hills and mountains, the volcanic eruption creates hills and clouds of ashes, the waves and tides are hitting the seashore, the rivers are running eternally, the whirlwind, whirlpool and black holes are gulping the things around, the glaciers are sliding down, the mountains are upside down, the top of the hill is going toward the bottom of the sea, planets, satellites, stars, comets and asteroids are in perpetual motion. Three canvases are assembled to capture the special moment of the flux but they can be dismantled and vanish at any moment. The artist traces infinite motion within us, in the world and beyond. Motion is the seed for birth, growth, development, climax and denouement of any real and fictional narrative. Such motion is invisible in front of us but the artist gives visible aesthetic shape to the invisible aspects.

\section{CONCLUSION}

Krishna Prakash Shah's abstract paintings provide rapture and delight through rhythmic waves, coherent colors, harmonious shapes and spontaneous movement. The compositions do not objectively represent the characters, objects and events of external world but subjectively suggest the invisible aspects of life and world through visible form. The colors and forms do not signify certain meanings but stand for their own sake. Aesthetic aspects are more dominant than the moral lessons. Joyful colors and harmonious shape convey a sense of sensation and music and viewers keep up their virtual motion along with unique tunes and melodies of music. The viewing subject swings with rise and fall as per the movement of the colors. The abstract paintings free us from the concerns of mundane matters and allow us to reflect on ourselves while viewing the compositions. The rapture and relish we receive reward us with unique aesthetic pleasure.

\section{REFERENCES}

Archer, W. G. (1989). India and modern art. George Allen and Unwin. Ausstellung Nepal (2015). Exhibition catalogue of artworks, Kunst Galerie, Germany. Beckett, W. (1994). The story of painting. London: Dorling Kindersley. 
Burke, D. B. (1986). In pursuit of beauty: Americans and the aesthetic movement. New York: Metropolitan Museum of Art.

Canady, J. (1959). Mainstreams of modern art. New York: Hult, Rinehart and Winston.

Denisoff, D. (2007). Decadence and aestheticism. Cambridge Companion to the Fin de Siecle. Cambridge: Cambridge UP.

Denney, C. (2000). At the temple of art. The Grosvenor Gallery, 1877-1890, Issue 1165, p. 38.

Dhungel, S. (2064, Asoj 30). Rangaka tarang. Rajdhani.

Fargis, P. (1998). The New York public library desk reference, 3rd Ed. Macmillan General Reference.

Gal, M. (2015). Aestheticism: Deep formalism and the emergence of modernist aesthetics. Peter Lang AG International Academic Publishers, 2015.

Gilbert, R. (1998). Living with art. Boston: McGraw-Hill.

Graham- Dixon, A. (2008). Art: The definitive visual guide. London: Dorling Kindersley.

Gurung, N.B. (2021, Jan 30). Kalakar Shahko rang utsav. Sahityapost.com, https://sahityapost.com/2021/01/26869/?fbclid=IwAR14Y6H5g9itUY3Kgf7Unzwvdf 5Wfvdv6cc2Qumhy cIOstS hYIktsNCCA (Accessed on 4 Jan 2021).

Kalkar Kultur and Geschichte: Exhibition Catalogue. (2017). Kunst Akademie, Germany. Kandinsky, W. (1977). Concerning the spiritual in art. New York: Dover.

Kant, I. (1992). Critique of judgment. In Hazard Adams (Ed.), Critical theory since Plato. New York: Harcourt Brace Jovanovich College Publisher, 376-386.

Khanal, K. (2019, Aug-Sept). Canvas. Yubamanch, 7.

Khanal, K. (2071, Asoj). Chitrama antarmanko abhibyakti. Yubamanch, 34-35.

Madhupark. (2009, Feb-Mar). Aawaran kalakar parichaya.

Martin, F. D. \& Jacobus, L. A. (1991). The Humanities through the arts. McGraw-Hill.

Matthews, R. T. \& Platt, F. D. (2001). The western humanities. Boston: McGraw Hill.

McMullen, L. (1971). An introduction to the aesthetic movement in English literature. Ottawa: Bytown Press.

Mendelssohn, M. (2007). Henry James, Oscar Wilde and aesthetic culture. Edinburgh University Press.

Pater, W. (1992).Conclusion from studies in the history of the Renaissance. In Hazard Adam's (Ed.), Critical theory since Plato. New York: Harcourt Brace Jovanovich College Publisher, 640-643

Rajdhanai (2012, March 27). Krishnaka chitrama manashanti.

Rebay, H. (1938). Value of non-objectivity. Third enlarged catalogue of the Solomon $R$. Guggenheun collection of non-objective paintings. New York: Solomon R. Guggenheun.

Saurya National Daily (2012, March 27). Shahka chitrabare antarkriya, 16.

Schapiro, M. (1979). Modern art. New York: George Braziller.

Seuphor, M. (1960). The spiritual mission of art. New York: Galerie Chalette.

Shah, K.P. (2012). My paintings: Presentation of inner feelings and emotions. Exhibition catalogue of Krishna Prakash Shah's solo painting exhibition, Kathmandu: K.P. Shah, 3-4. 
Shah, K.P. (2021). Nepali abstract paintings: A development analysis. Kathmandu: Nepal Academy of Fine Arts.

Shah, K.P. (2021, September 12). Interview. Lalitpur.

Shah, S. (2007). Real salvation: Exhibition catalogue of Krishna Prakash Shah's paintings. Kathmandu: K.P. Shah.

Sharma, Y.P. (2012). Krishna Shah's paintings: Exploring ourselves through musical colors. Exhibition catalogue of Krishna Prakash Shah's solo painting exhibition, Kathmandu: K.P. Shah, 7-8.

Sharma, Y.P. (2014). Nepali painting: A critical analysis. Kathmandu: Nepal Academy of Fine Arts.

Sharma, Y.P. (2021). Visual rhythm in Krishna Prakash Shah's abstract paintings. SCHOLARS: Journal of Arts and Humanities, 3 (1), 10-17. https://doi.org/10.3126/sjah.v3i1.35354

Welland, D. S. R. (1953). The pre-Raphaelites in literature and art. London: George G. Harrap \& Co. Ltd. 